\title{
The Edi Mancoro's Religious Tolerances Model in Countering Digital Radicalism
}

\author{
Nur Ahmad ${ }^{1}$, Akhmad Arif Junaidi $^{2}$, Muhamad Afifudin Alfarisi ${ }^{3}$, Nurul Uzdhma Tastia ${ }^{4}$ \\ Universitas Islam Negeri Walisongo Semarang, Indonesia ${ }^{1,2,3,4}$ \\ \{n.ahmad@walisongo.ac.id ${ }^{1}$, arif junaidi@walisongo.ac.id ${ }^{2}$, alfarisi324@gmail.com ${ }^{3}$ \}
}

\begin{abstract}
The research aims to examine the tolerances implementation in Edi Mancoro's Islamic Boarding School to counter the intolerances on digital radicalism. The tolerances model in Edi Mancoro's Boarding School (Pondok Pesantren Edi Mancoro) works to the student (santri) to keep tolerance among other religious believers. One of the Edi Mancoro's Models of Tolerances could counter intolerances on digital radicalism is the pluralism teaching concept by Kiai Muhamad Hanif which is a focus on respect to the others' religion. Teach by using perspectives, to see what the interest of other religions and what things could be mediating among the conflicts. As far as the study for peace religious, radicalism transforms from massive community-based to cyber media, the community of religious intolerances uses the media advantages to penetrate people or society to obtain followers. Therefore, religious intolerance intensively penetrated vulnerable people. Make use of the Edi Mancoro's model of tolerances, this research tries to analyze what important aspects of tolerances or pluralism model relevant to the digital era. In addition, the study of Edi Mancoro's model of tolerances would engage the socio-culture, religions, society, and digital media.
\end{abstract}

Keywords: Religious Tolerances; Digital Radicalism; Pluralism

\section{Background}

\subsection{The Profile of Edi Mancoro's Boarding School}

Edi Mancoro Islamic Boarding School is located in Bendungan, Gedangan Village, RT 02 RW 01, Tuntang District, Semarang Regency, Central Java. The Gedangan Village located in the middle area of the foot of the Merbabu Mount and around Rawa Pening, thus Gedangan has territory plantation, forestry, and paddy fields. The territory of topography 500 meter above the surface of the sea and the temperate tropical temperature range $20^{\circ} \mathrm{C}-30^{\circ} \mathrm{C}$ so that makes Gedangan Village a cool area, and suitable as a stopover.

Gedangan Village is a village with economic potential because part of the community's income depends on their rice farming. Besides, the source of income that is not less reliable is from dry agricultural products. Besides, Gedangan Village is one of the villages producing fruits such as lansium domestic, bark, rambutan, and others. For this reason, Gedangan Village has been dubbed the village of self-sufficiency.[1] 
Edi Mancoro Islamic boarding school is a type of semi-modern Salafiyah boarding school. Edi Mancoro has all aspects of the elements of the base which is categorized as pesantren salaf, namely the clerics or teachers teaching to their students, their boarding as were boarding students, the yellow book as curriculum education as well as the mosque as a means of study and worship. Unfortunately, not all the surrounding communities are obeyed and submit to the teachings of Islam. Therefore, the local religious leader establishes a cottage boarding schools which means teaching Islam, (tafaquh $f i$ ad-din) and the develop the character of santri to decreasing the bad habits.

\subsection{Student's (santri) Social Interaction}

The Santri's live at the Edi Mancoro Islamic Boarding School focusses to learning Qur'an and formal study. In the other hand, various santri including student at university of IAIN Salatiga which they are also actively involved in social and organization activities. Followers undertake the social engagement such Village Community Organization lead by Kyai Mahfudz Ridwan, even to the Non-Governmental Organization in Jakarta which owns it with Desaku Maju. Noted about 25 villages guided by the Desaku Maju Institute for community welfare and empowering programs such as cooperatives, employment training, and drought resolution. The Desaku Maju Foundation also helps resolve problems of religious harmonies, helping Christians to build a church and others.[2]

On the other sides, the Edi Mancoro Islamic Boarding School cooperates with Percik, an interfaith community in Salatiga to carry out several religious activity's missions. To date, it has succeeded in creating branches of interfaith organizations, such as the old, young and even children FSUB (Forum Serasehan Umat Beragama). The Edi Mancoro Islamic boarding school students continued to actively participate in religious tolerance activities, solve problems and implement the community tolerance.[1]

Nowadays, the Edi Mancoro Islamic Boarding School has established many religious organizations such as OSEM (Edi Mancoro Santri Organization), Press Media and MRI (Mahfudz Ridwan Institute) which more or less hold seminars or group discussion forums on religious tolerance. They invite religious leaders or interfaith students to chat and exchange knowledge, for example at the Multicultural Seminar held on Saturday, March 7, 2020, the committee brought Romo Aloysius Budi Purnomo and Bikuni Sammodana to discussion. The interaction between santri and interfaith leaders are related to taboo matters but also provides an understanding of tolerance.[1]

For example, the several community organizations that exist at the Edi Mancoro Islamic Boarding School train students to gather and directly going to the community, such as KBIHU (Hajj and Umrah Group), Laziskaf (Charity and Zakat), and BLK (Work Training Center).[1] The Edi Mancoro's make use of place to implementation of leadership development. The students could be accustomed to being flexible and responsive faced to the social communities as well as with an interfaith colleague.[2]

\section{Religious Tolerances Framework}

\subsection{Model of Kiai Leadership}

The Kiai leadership described the hold on santri's practical of Mystical Javanese Tradition with primary obligation such complement element among people. KH. Mahfudz Ridwan, 
become son in law too therefore happened about scientific transmission continuously among teacher in kyai's big family. Kiai empowering the religious authority based on Javanese values tradition which was only believed by santri. However, the society who appeared the charismatic leadership formed a strong spiritual personality in knowledge transmission, for example of strong personality in Pesantren established by all rules of Edi Mancoro's School.

The muslim scholar from Maroko, Abu Hasan Syadzili well-known in Indonsia, in particularly Kudus-Salatiga. In praxis, KH. Mahfudz Ridwan constantly use Syadziliyan ritual as the basic spirituality of teacher and santri. The Sadziliyan followers recite Dzikr loudly for a hundred times. Moreover, characteristics of Syadziliyah it is Da'wah (Public Speaking) on social issues to the followers.

\subsection{The Boarding School Curriculum}

The educational model in Pesantren Edi Mancoro is maintains the classical system. Teaching in traditional model called wetonan and sorogan. Both educational systems are prayer and Islamic preachment in the Sunday morning. The wetonan, for instance, held in an open lecture, Kiai recite the Pegon books (yellow paper based) and transformed the Kiai's understanding to the Jamaah or followers.[3] The books contain: fiqh Sulam Taufiq, Taqrib and Fathu/Wahab which is only provided by santri. The language in order to recites the books or pegon is Arabic, make use of Nahwu (grammatical) and Sharaf (lexicall). In the 1999, public election, for instance, KH. Mahfud Ridwan allowed a woman to be president based on the juristic arguments supported by willingness people. He frequently said a fatwa against the politic views of Muslim in Fiqh orientation study on worship, such as the ways of prayed or pilgrimage and marriage. Santri also study fiqih muamalah such as a commercial law.

\section{Results and Discussions}

\subsection{Edi Mancoro's Model of Religious Education}

There is spiritual systematic learning composed by Pesantren Edi Mancoro based on cultural transformation. In order to obtain the deep spirituality, schools teach the relationship between fundamental Islamic values and Javanese culture. Also, on the digital era, cultural transformation has been changes. Learning models, for example, could be overcome with the Internet, which means subordination to positive or negative impact, and teaching has been transformed.

As far as known, the traditional model of education or learning system related to the Islamic values, humanity, ethic concepts of Pesantren. Offering the spirituality based on Holy Qur'an and discipline learning. On the other hand, Javanese culture has been assimilated with pesantren in form of prayers traditions. Thus, the existence of Islam was not subtitled or replaced by local culture elements as well as culture.[4] Therefore this sub-culture position in the development process supported by santri who called with autonomy social community.

Based on experience in the preservation of the santri tradition decided by two sociology factors, firstly, the leadership of Kiai figures by KH. Mahfudz Ridwan who took the role as a leader for a caretaker of Islam tradition that probably to be continuously for santri. Secondly, the curriculum as the education of yellow book as priority transmission media for Islamic studies has being a characteristic of Islamic holding. However, the tradition in Pesantren was not static and passive but could be transformative. That changes could be influenced by two 
factor variables of social tradition, firstly, the interaction of social santri with the social culture environment where the organization established and took a role. In views of pesantren Edi Mancoro, wherever the conflict undertakes seems to necessarily be balanced between reality and peaceful values. Second, the patterns of social interaction of santri in the school and the plural world. For instance, obtain the atmosphere of the Christian society in peace and respect, not make them angry, worry, or uncomfortable. Interaction between calm and peace of santri maintaining neither at school nor in society. To sum up, santri's tradition should build a strong character in the religious aspect.

The jurisprudence in socio-religious and social phenomenology formed intrinsic by Islamic values with santri's world view. Therefore, the transformation process keeps moving forward to the religious authority which hold Fiqh values of Islamic supremacy with the rules and principles: to preserve a past history as good and took a new good thing in the contemporary. The religious authority of santri Pesantren Edi Mancoro standing based on the implementation of fiqih that lighted by sufism values where fiqih was internalized as an important thing from the experiences. Thus, the appearing of religious authority unproduced the tradition trustly, decrease of spiritual dimension and not be changed as the authority has been enlightened by sufism. The elements of inner knowledge that came from the spiritual experience that has got through the preservation of religious ritual. The elements of fiqih that lightened by tasawuf could appear Islamic religious authority. Once more, the religious authority with mystical spiritual values supported Islam through the transformation process with the outside world through the influenced of reciprocal from social process. In use of this transformative mechanism, the process of accepted happened, recognized and trusted.

\subsection{Overview on Santri and Radicalism through digital tools}

The shifting culture has been fairly strict had made the education for all sectors changes. Learning in any form has undergone a transformation, either in the form of method or material or content. In this context, the demands of the santri are not only to learn spirituality, but also to learn technology-based knowledge. In use of technology devices such as computers and smartphones are a learning network of the Internet or websites. Despite, it cannot be denied that technological devices are among the easiest to become intermediaries for terrorism networks in order to gain new followers or carry out propaganda. At least, it is necessary to understand the development of the internet in Indonesia, its spread and the medium of terrorism that has occurred.

The internet at first uses at the University of Indonesia (UI) in 1983 which held by the Department of Computer Science in Jakarta. The association initially interfaces with UU Net in the United States. Simultaneously, the Indonesian government gets the lasting Internet associations it was ISPs. In 1994, PT Indo Internet has framed the primary business ISP (Internet Service Provider). An early client of the Internet comprises to analysts in nonbusiness and diversion networks.[5] The normal term "warnet" alludes to the "Warung Internet" that was set up in 1996. The Asia Pacific Networks Information Center distributes bulletin it was roughly 1,500 warnet spreading in Indonesia. These digital bistros are giving 60 to 70 percent of Internet access in Indonesia. Merlyn raises consideration regarding the urgent of comprehension the warnet on the off chance that it was one huge effect of the web in Indonesia.

In 1998, the organization offers warnet with a further developed PC. Beginning to had the spot at school just as college-based organizations, set up web bistros hence expanded standardization of web use. These days, individuals utilize the Internet in the workplace, 
school, colleges, and Islamic life experience schools. Indeed, even warnet keeps on existing today and assumes a significant function in the improvement part of data and innovation in Indonesia which gave Internet admittance to the resident who can't bear the cost of their own personal PCs and the membership charge.

In the large catch, supplier web access is still tormented with the issues of separation and admittance to the populace in far off territories and uneven zones. In the Indonesian Maps, the separation between any a few islands is extensive. Indeed, even inside an island, the separation between urban areas is far separated. Thusly, giving access web in distant and lesser populated territories is a critical test in Indonesia. In 2013, The Indonesian Internet Service provider Association (APJII) captured was internet reached 71.19 Million users.[6] Besides, in Asia internet use, reports by internetworldstats.com, Internet population in Indonesia reach 171.260 million which was $62.6 \%$ penetration population in use of Internet. Currently, the Internet transform the "traditional" pattern of mass media in conveying information such as newspaper, television, and radio, the exponential upgrade figures that, every year, it is becoming an increasingly crucial tool for work and acces information worldwide.

The background of Indonesian user profile of Internet is necessary to understanding before attempting to knowing Bahasa Indonesia radical website's narratives and operation. Based on Merlyna Lim research concerning, the typical of Indonesian Internet user's dominant as young individuals, based in urban areas which are the Internet is more likely to be easily accessible. It could be aforementioned in the office and institution in particular. Merlyna noted that increasingly percentage of the user internet tend to be male.[7] The contents of Indonesian radical sites, which most part is by all accounts composed by men for a male user. Then again, the substance seems, by all accounts, to be an expanding number of the female crowd, which accommodates Lim's exploration that there is more lady who as of late uses the Internet.[7]

Bahasa Indonesia's radical site is as yet centered around purposeful publicity spread. It usually utilizes the use of pictures, PC backdrops, influential way of talking, and recordings to convey the enduring of individual Muslims around the globe. All things considered, the substance on the sites propose the crowd to the favored answer for the issue. In the Marc Sageman perception, "the mass idea of Internet correspondence supports audio clips and other reductionist responses to troublesome inquiries. Reached to their legitimate determination, these perspectives energize extraordinary, conceptual, yet shortsighted arrangements, regardless of the truth and unpredictability of life."[8] There are no contrasts between extremist destinations with "typical" locales in this worry. The brutality in pictorial structure empowers simply such a shortsighted answer for the issues of the Muslim world. As such, promulgation could be delivered as substance which are recordings and articles on the sites. The Bahasa Indonesia sites flourish with paranoid fears or essentially negative depiction of the West and other saw foes. In Indonesia for Instance, Hizbut Tahrir Indonesia (HTI's) site in November 2007 Highlights this. HTI's delivered an extensive rundown of political improvement around the globe and in Indonesia that occurred in the long periods of September and October 2007.

Furthermore, radical website also sells online product online to keep funding safety, and its running in Arrahmah Media Website. The company based in Jakarta, on the International group's views, the product sale VCDs from Jihadist and al-Qaeda websites. In 2007, the company starting to sell book titled "Tiada Khilfah Tanpa Tauhid (There can be no Chaliphate without Tauhid and Jihad). The company also launched a magazine in March 2008, titled Jihad Magz which is distribute at the Islamsic Book Fair. The examples figures that the Organization not only operate propaganda through Internet, but also composing the 
books to obtain more followers.

\subsection{Implement the Dialog Model}

Refers to the common terminology, deradicalization is the reverse of radicalization. The term refers to meaning as "the result of rejecting and authoritarian ideology and realizing that it is not necessary to use aggression to bring about social change." Following the outline of the radicalism through digital ways, reversing the ideology must be inherent with the practical as undertaken by santri's in Edi Mancoro's school. The models of religious tolerance are based on the Qur'anic Exegesis. Kiai Mahfud begins withthis Qur'anic verses experience, which is: Verses Al-Hujarat 13 and Verses Ali-imran 64

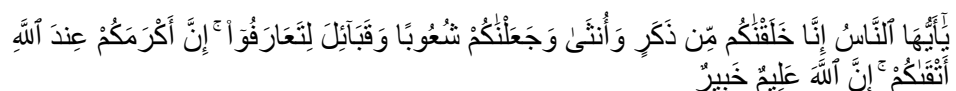

O people, indeed We created you from a man and a woman and made you nationals and tribes so that you knew each other. Surely the most noble among you by Allah is the most pious among you. Truly Allah is All-Knowing, All-Knowing. (Al-Hujarat: 13)

The verses explained by Kiai Mahfud such as respect and love to others among us. Implementation of religious tolerance seems to be an actual experience of respect to another religions. In the other hand, to obtain sharply understanding of religious tolerance in use of counter digital radicalism, Karl Manheim propose the concepts of dimension both behavior and meaning. Capturing society by lens of digital tools seems to only seeding the dimension of meaning, incomplete the situation or behavior dimension. Manheim, in particularly focus on the three differentiating the social action into three parts. First of all, meaning of the objective, could be understood as the correlation between social context and the actions. Second, impressing meaning with an impressive emotion and it explained as a praxis of actors could be affected by historical experience. Third, the documentary meaning which deeply manifestation of culture.[9]

Following the Manheim views, shifting from traditional to the digital cultures affects the school and its students. The meaning determines by context of the Society which placed the action. Thus, meaning the objective of implementing the tolerances of religion in Edi Mancoro's includes: to begin with, the exercises of execution of resilience of religion in Edi Mancoro Islamic Boarding held with different models of functions, for example, visits, seminars, discoursed, outdoors cross confidence, and others. Also, the execution of the resistance of religion in Edi Mancoro Islamic Boarding which is restrictive, isn't any time are fixed or routine in its usage, however following the necessities or solicitations from inside and outside schools. Then, the length of the conveyance was following the arrangements of the coordinators of the exercises. Some are done one day, for example, multicultural classes, Interfaith Journey, and others. There is likewise, an even until life in schools to follow the exercises exceptionally pesantren, for example, the visit of the University of Kristen Satya Discourse, visit Sanata Dharma, even ahead of time when Kyai Mahfudz was as yet solid, numerous visitors from far off nations to remain 3 weeks old to learn religion and life in allinclusive school. Third, the usage of resilience of religion isn't just done by the understudies, yet in addition, sometimes followed by different gatherings from outside the schools, the two Muslims and nonMuslims to join an exchange about resistance of religion, even not rarely the 
heads of religion across confidence meet up to examine issues of social or similarly as an asset for a cross-confidence discourse.

Fourth, in the term of coordinators the exercises shift. On the off chance that the execution of the movement is a support from the pesantren, the coordinators are the understudies who are affirmed by the parental figure. For panel got from a blend of understudies, most of the board understudies or OSEM (Organization Pupils Edi Mancoro), heads MRI (Mahfudz Ridwan Institute, and understudies of non-association. Then, if the movement is support from outside schools, the board could be cooperation on the two sides of them or is restrictive. to act as an illustration of exercises visits from understudies of a college, at that point they just come in and follow the exercises of the visit, and as advisory group supplier needs and installations are of Edi Mancoro's understudy.[1] The attribute action such as an actor means marked by the practice of a character refers to the personal history. In the Gus Hanif views, Kiai Mahfudz applied strongly the idea of pluralism while was study in Baghdad with Gus Dur. In 1985, discussing the spirit dialog of religious with Gus Dur, Romo Mangun and Kiai Mahfudz in Kedung Ombo.

\section{Conclusion}

The target significance of executing strict resilience in Edi Mancoro Islamic Boarding School is as per the following: First, the movement of actualizing strict resistance in Edi Mancoro Islamic Boarding School is held with different models of functions, for example, visits by interfaith pioneers, strict courses, interfaith discourse, interfaith camps, and so on Second, the execution of strict resistance usage in Edi Mancoro Islamic Boarding is led restrictively, there is no fixed or routine time in its execution, however it relies upon the requirements or solicitations from inside or outside the Islamic Boarding School. The length of the function was led by the movement coordinator. Third, the execution of strict resilience isn't just completed by the understudies yet in addition followed by different gatherings from outside the Islamic Boarding School. Fourth, regarding the coordinators of the exercises fluctuated. On the off chance that the execution of the movement is a support from the pesantren, the coordinators are the understudies who are affirmed by the guardian. Though if the action is support from outside the pesantren, the advisory group can cooperatively from the two players or be restrictive. Notwithstanding, the expressive importance completed by Kyai Mahfudz likewise shared by any individual who has been an entertainer in the execution of strict resistance, which can be closed as follows:

a. Interfaith discourse is acknowledged vital and critical to keep on being maintained in the life of society and the state.

b. Santri acknowledges and accepts that these exercises can sharpen the soul of patriotism, pluralism, and communism, impersonating the battling soul of Kyai Mahfudz.

c. Members in interfaith discourse exercises need to comprehend the real essence of resistance and make it a guide of information in high resilience network life.

d. The execution of strict resilience is acknowledged as though it blurs away all doubt between networks across religions and sparkles harmony and thriving.

e. Be a confidence enhancer and spark of acquiescence in loving each other's religion and convictions.

The importance of the Documentary, in particular the concealed significance of the usage of resilience in religion at Edi Mancoro Islamic Boarding School 


\section{References}

[1] Nurul Uzdhma Tastia, 'The Implementation Of Religious Tolerance In Edi Mancoro Islamic Boarding at Gedangan Tuntang Semarang, Central Java', State Islamic University of Walisongo, 2020.

[2] M. Masroer, 'Religious Inclusivism In Indonesia: Study of Pesantren An-Nida and Edi Mancoro, Salatiga, Central Java', ESENSIA J. Ilmu-Ilmu Ushuluddin, 2018, doi: 10.14421/esensia.v19i1.1485.

[3] N. U. Tastia, 'An Interview with Kiai Mahfud Ridwan', Salatiga, 2020.

[4] M. M. Nafis, 'Pesantren dan Pluralisme: Upaya Modernisasi Pendidikan Pesantren Menuju Masyarakat Madani', Insa. J. Pemikir. Altern. Kependidikan, 1970, doi: 10.24090/insania.v13i2.297.

[5] Apster, 'The Internet Of Indonesia', Apnic. http://archive.apnic.net/emails/apster/pdf/apster21-200702.pdf (accessed Oct. 04, 2020).

[6] APJJI, 'Survei Penggunaan Internet Sektor Bisnis 2013', website, 2013. .

[7] M. Lim, 'Social History of Internet', Internet, 2007. https://web.archive.org/web/20070830153736/http://dialogue.mediaculture.org.au/node/20.

[8] J. Magouirk, S. Atran, and M. Sageman, 'Connecting terrorist networks', Stud. Confl. Terror., 2008, doi: 10.1080/10576100701759988.

[9] G. Baum, Religion in the Shadows of Relativism: An Analysis of the Sociology of Karl Manheim's Knowledge of Syntheses of Historical Normative Truth, Terj. Achmad Murtajib Chaeri. Yogyakarta: PT. Tiara Wacana, 1999. 